\author{
Hanna Wiczanowska \\ Adam Mickiewicz University \\ Łukasz Szoszkiewicz \\ Adam Mickiewicz University
}

\title{
The Protection of the Right to Education in Minority Language: the Council of Europe's Standards
}

\begin{abstract}
There is neither consensus whether the category of linguistic rights shall be distinguished, nor international agreement on the catalogue of such rights. Nevertheless, access to education in mother tongue constitutes a core element of most of the international and national frameworks of minority protection. Academic and legal disputes are particularly absorbing in Europe, where linguistic policies frequently intertwine with politics (e.g. Cyprus, Moldova, Ukraine). Thus, it is essential to pose the question, whether the right to education in mother tongue is always granted the equal scope of protection or is such protection differentiated by any additional criteria. Most of all, it shall be considered whether the analyzed right has an independent character or its protection is associated with perception of other fundamental rights and freedoms. This paper investigates the scope of the protection of this right within the framework of the Council of Europe.
\end{abstract}

Keywords: linguistic rights; right to education; ECHR; ECtHR; minority rights; UDHR

\section{Introduction}

The objective of this paper is to conduct an analysis regarding the scope of protection of the right to education in the mother tongue for minorities within the legal standards adopted by the Council of Europe. The authors primarily focus on the European Convention on Human Rights and Fundamental Freedoms (taking into consideration its Additional Protocol No. 1 and jurisprudence of the European Court of Human Rights (hereinafter ECtHR). The study is supplemented with the analysis of the European Charter for Regional and Minority Languages (hereinafter ECRML) adopted in 1992 and the Framework Convention for the Protection of National Minorities adopted in February 1995 (hereinafter FCPNM). 
The last two documents are recalled as a benchmark for the rapid change in the judicial practice of the ECtHR regarding the presented matter. Subsidiarily, the authors elaborate on the opinions of the European Commission for Democracy through Law (hereinafter Venice Commission). The initial part of the study is undertaken upon the basis of historic method to clarify the link between the travaux prépraratoires of the regulation prescribing right to education in minority language, commencing with the Universal Declaration of Human Rights (UDHR) and the current scope of this right. The latter part of the article is prepared within the usage of subsequent methods: dogmatic legal method and comparative analysis to juxtapose the protection mechanisms constituted within three presented legal instruments. Such conducted analysis aims at resolving the issue of coherence within the aforesaid documents.

\section{What Does the Travaux Préparatoires to the Convention Unveil?}

Framework established by the Council of Europe delivers relatively laconic and vague formulation of the right to education. Article 2 of the First Additional Protocol to the Convention (hereinafter P1-2) limits itself merely to the statement that "[n]o person shall be denied the right to education" (first sentence) and prescribes the right of parents to ensure that education and teaching remains in conformity with their own religious and philosophical convictions (second sentence). Undoubtedly, the formulation of the right to education in the above mentioned and subsequent instruments of international human right law can be traced back to the UDHR adopted in 1948. Its Article 26 proposed the very first wording of the right to education and as such served as a departure point for the discussions over the final text of the European Convention on Human Rights (1950) (Council of Europe, 1967, p. 12).

Discussions over the formulation of the right to education were among the most timeconsuming during the drafting process of the Convention (as this right was originally to be placed in the Convention, not the Protocol), however the issue of minorities' education was marginal. For instance, the problem of language was raised only once - at the ultimate phase of the drafting process - by Denmark. Its delegate proposed to include the linguistic component into the provision establishing right to education. The proposal read as follows: Parents or others in charge of the education of children shall have the right to decide freely that children in their charge shall attend recognized schools with another teaching language than the language of the country in question (Council of Europe, 1967, p. 133). Although it may appear to impose too far-reaching obligations on the States, its perception back in 1950s was quite different than it would be nowadays.

Minority rights were placed high on the agenda of the League of Nations and the guarantees regarding education constituted an inseparable element of the treaties signed between the Principal Allied and Associated Powers and the defeated or newly emerged states (Cumper \& Wheatley, 1999, p. 269). For instance, Article 9 of the Treaty with Poland (1919) stated that "Poland will provide in the public educational system in towns and districts 
in which a considerable proportion of Polish nationals of other than Polish speech are residents adequate facilities for ensuring that in the primary schools the instruction shall be given to the children of such Polish nationals through the medium of their own language". The issue of language in education was subsequently subjected to advisory opinions of the Permanent Court of International Justice (for instance: Access to German Minority Schools in Upper Silesia, Advisory Opinion, 1931). Interestingly, education received the widest possible protection by imposition on the states the obligation to ensure (and thus, to allocate sufficient funds) that teaching in primary schools is undertaken in minority languages. It may clarify why the Danish amendment to the Convention did not meet with the strong opposition. Indeed, travaux préparatoires confirms that some delegates were able to agree on it - its inclusion would be more likely, if it was tabled earlier in the drafting process (Council of Europe, 1967, p. 135).

The lack of explicitly established linguistic rights in the context of education does not necessarily mean that those fall out of the scope of the normative content of the P1-2. Suffice to say that the drafters of the UDHR were convinced that the general anti-discrimination clause guarantees an adequate protection of minority rights, including the right to teaching in minority languages (Schabas, 2013, p. 2680). Thus, it was the main reason for which the proposal of amendment adding extra anti-discrimination clause was rejected during. The amendment regarding the right to receive teaching in minority language in non-public schools suffered the same fate. Nevertheless, the linguistic rights in education received some attention during the process of drafting the UDHR and did not meet with any fundamental opposition. Likewise, this issue did not give rise to any controversies while drafting the Convention and could have been arguably incorporated into the final text if some delegations were to advocate for its inclusion. Therefore, it may be claimed that the intention was not to unambiguously exclude the linguistic rights of minorities from the scope of the provision P1-2. Thus, the laconic formulation of the right to education gave room for the Court to determine the scope of the State's obligations what contributed to the numerous discussions over the compatibility and coherence of the frameworks established by the United Nations and the Council of Europe. Frequent references made by ECtHR to the UN instruments when dealing with complaints relating to the right to education raise more questions than give answers (Catan v. Moldova and Russia 2012, \$77-78). Ironically, the first case before the ECtHR regarding the right to education concerned language (Belgian Linguistic Case, 1968).

\section{The Initial Phase of ECtHR Approach: a Lack of Protection}

Firstly, it is essential to consider the issue if the right to receive education in the national language of certain minority group is encompassed by the scope of the provision of P1-2. In this context, the authors pose the question if a right to receive education in the mother tongue of certain minority can be encompassed with the scope of the general right to 
education as stated within the Convention. As already proved, the travaux préparatoires confirms that the object of the second sentence of P1-2 was in no way to secure respect by the State of a right for parents to have education conducted in a language other than that of the country in question. Such remarks were subsequently confirmed by ECtHR in the Case relating to the certain aspects of the laws on the use of languages in education in Belgium versus Belgium (hereinafter Belgian linguistic case). In the circumstances of the presented matter the applicants pointed out that they are French-speaking or that they express themselves most frequently in French, they want their children to be educated in that language.

To reconstruct the scope of protection of $\mathrm{P} 1-2$, it is essential to focus on the aim of the aforesaid provision, which is to guarantee all persons the right to avail themselves of the means of instruction existing at a given time. As the Convention shall be interpreted as a whole, the right to education is to be understood through the prism of its Article 14 (the prohibition of discrimination). However, in the opinion of ECtHR, these two provisions read in conjunction do not confer the right to obtain instruction in a language of applicants' choice. In other words, the only situation which allows for the protection in similar cases is when the linguistic distinctions are of arbitrary character (Belgian Linguistic Case, 1968, § 39-40). The purpose of Belgian provisions was to prevent the establishment or maintenance of schools which were teaching only in French. Such a measure was based on the objective criteria and associated with the notion of public interest elements which are constituted by the specific features of the regions (Belgian Linguistic Case 1968, $\$ 40$ ).

The presented judgment is burdened with internal incoherence as the final conclusion of the Convention collides with the notion that for the efficiency of right to education, its beneficiaries should have the possibility of drawing profit from the education received. Such a principle pertains to the link between education process and understanding one's identity. The language of certain minority group is one of its most fundamental elements. The ECtHR refused to resolve the issue whether maintaining teaching in a language essential for a certain region could be justified by other means available. Furthermore the notion that the domestic regulations did not prevent possibility to organize education in minority language without any legal justification transfers the burden of protection and fulfillment of human rights from the State to the individuals themselves. Such construction poses serious doubts regarding the efficiency of human rights protection mechanisms.

The grounds for the presented approach of the ECtHR arise first of all from the origin of fundamental interpretation rules of the Convention, such as the margin of appreciation doctrine (Arai-Takanashi, 2002, p. 43; Christoffersen, 2009, p. 29). Moreover, the Belgian Linguistic case has also been the first casus of implementation of a formula of "weighting and balancing" in which rights will be accorded particular importance rather than absolute protection. In this context, one shall agree with Howard C. Yourow who stated that the ECtHR has not developed any precise weighting and balancing formula, although major interests have been identified (Yourow, 1996, p. 27). 
The presented approach has been subsequently confirmed in the judgment of Skender v. the former Yugoslav Republic of Macedonia which was declared inadmissible (Skender v. Macedonia, 2001). Within the aforesaid case, the ECtHR expressly stated that the linguistic issues fell outside the scope of the Convention. Furthermore, even within the initial period, the judicial practice of ECtHR can be characterized with incoherence and lack of legal foreseeability as in Belgian Linguistic case the ECtHR ruled the judgment on the merits, while the Skender case was held inadmissible (Koch, 2009, p. 164).

\section{Cyprus v. Turkey and Catan: Judicial Twists or Return to the Roots?}

In the Cyprus versus Turkey, the ECtHR delivered opinion that was subsequently interpreted as a potential 'jurisprudential reshuffle'. In the presented case, the Cypriot government complained that although primary education was available in Greek, the Turkish republic of Northern Cyprus had closed down Greek secondary school. The Court firstly reiterated that the violation of the right to education in strict sense did not occur. Nevertheless, oppositely to the previous cases, it held violation of the provision of $\mathrm{P} 1-2$. The rationale for such a decision was the fact that having provided a primary education in Greek it was unrealistic to expect children to undergo the language shift to Turkish once they have already reached secondary age (Cyprus v. Turkey, 2001).

Such a tendency has been maintained in the judgment of Catan and others v. Moldova and Russia (hereinafter Catan case) regarding the use of language in schools in the disputed area of the Moldovan Republic of Transdniestria (MRT). The official language of the MRT was Moldovan, however in 1992 the newly enacted law declared that it must be taught only in the Cyrillic alphabet. As a consequence, all schools were forbidden to teach in Latin script and the schools that did not respect such regulations were refused to be registered or their teachers and students suffered abuses (Catan v. Moldova and Russia). The ECtHR held that the provision of P1-2 must be read in the light of Article 8 of the ECHR (the right to respect for private and family life). The applicants parents were placed in the invidious position of having to choose between sending their children to schools where they would face the disadvantage of pursuing their entire secondary education in a combination of language and alphabet which is unrecognized anywhere else in the world, using teaching materials produced in the Soviet times or subjecting their children to long journeys or substandard facilities, harassment and intimidation. As a result, the ECtHR appears to state, in certain circumstances, the failure to provide education in the mother tongue may, in fact, violate the right to education itself (Catan v. Moldova and Russia, 2012; $\$ 143$ and $\$ 144$ ).

One may interpret Cyprus v. Turkey or the Catan case as the unexpected turning points that resulted in broadening the scope of the right to education. The authors claim, however, that the final judgements flow straight from the fears that accompanied drafting the Convention. The issue of language - although seemingly in the foreground, most of all 
in the Catan case - served merely as a proxy for the real underlying concern, namely the protection of children from the undue interference by the State.

Travaux préparatoires to the ECHR unveil that one of the issues which was consequently returning during the negotiations was the fear that the politicization of education pursued by the totalitarian regimes inevitably leads to the subjugation of individuals to the State. The drafters of the Convention were of firm belief that children shall be the ends of the educational system, not the means for entrenching particular ideology (Council of Europe, 1967, p. 16).

Indeed, Cyprus v. Turkey (2001) was the first case that, in many respects, demonstrated similarity with the developments that accompanied the establishment of the non-democratic regimes in the past. The educational and linguistic policies of the Turkish Republic of Northern Cyprus (TRNC) were clearly subordinated to the needs of nationalistic political agenda. Beside the closure of Greek-language secondary schools, the TRNC authorities engaged inter alia in the excessive censorship of textbooks (the ECtHR found it to constitute violation of Article 10). Moreover, the Commission pointed out, the TRNC authorities made no effort to guarantee that this process was done "in accordance with law" (European Commission of Human Rights, 1999, \$ 459). What's the most important, though, is that these alleged violations formed only a part of the machinery intended for the reinforcement of the TRNC regime. Suffice to say, that up to the Catan case, the ECtHR issued judgments in other cases against the Turkish/TRNC authorities that concerned, for instance, the right to property (Loizidou v. Turkey 1996) or the right to respect for private and family life - and the TRNC authorities were generally found in breach of the Convention (Özersay, Gürel, 2009, p. 273-291).

In the Catan case, the ECtHR was more straightforward and described language policy adopted by the MRT authorities as being aimed at the Russification of the Moldovan community living in Transdniestria (Catan v. Russia and Moldova 2012, $\$ 144$ ). Interestingly, the Court linked the right to education in mother tongue with the aims that the education should achieve, most of all with the full developments of child's personality. This argument, again, revokes association with the UDHR. Unfortunately, as Judge Kovler pointed out in his dissenting opinion, the applicants did not provide enough evidence regarding curriculum imposed by the MRT authorities (A. Kovler, Partly Dissenting Opinion to the Catan v. Russia and Moldova, 2012).

As it has been observed, the recent development regarding the right to education in mother tongue were triggered under specific circumstances. In the analyzed cases, the authorities of self-proclaimed republics used educational and linguistic policies as weapons in the political conflict. It provokes a question, whether the ECtHR would ensure such a scope of protection as to the protection of minority rights, if the case was free from the politics. Either way, both judgments may be interpreted as an attempt to protect individuals against an unlawful interference by the State. In this context, the issue of language was used as a proxy that allowed to keep the ECtHR aside of the political conflict while ruling 
in favor of the protection of minority rights. It may explain also, why the ECtHR did not elaborate much on the issue of school curricula in the Catan case while the issue of the censorship of textbooks was considered only in the context of Article 10. Thus, any further judicial developments in this matter are dependent on the subsequent applications and their underlying political tensions.

\section{Grounds for Evolution of the ECtHR Practice}

As expressively stated in the Catan case such a margin increases with the level of education which means that primary and secondary education is of particular protection. Moreover, the judicial practice regarding the right to education in minority language has been from the very beginning fight between static and dynamic approach to the Convention interpretation (Yourow, 1996, p. 28).

However, one shall not forget the external factors which influenced the change in the approach of ECtHR. One of the most crucial was the enactment of the European Charter for Regional or Minority Languages (hereinafter ECRML) adopted in 1992. One of the main features of ECRML is its purpose to protect the cultural assets of Europe, namely the linguistic diversity represented by minorities. Consequently, the analyzed document emerged from refining the traditional shape of protection from minority groups towards the protection of the languages themselves. As a result, unlike the ECHR, the Charter does not define rights held by the particular categories of person, whether individuals or groups (Woehrling, 2005, p. 27-28).

From that perspective, the enactment of ECRML significantly contributes to raising awareness of the importance of minority languages. According to the Article 4(1) nothing in this Charter shall be construed as limiting or derogating from any of the rights guaranteed by the Convention. Consequently, in case of any doubt as to the scope of Charter provisions, it must be interpreted in a manner that is consistent with the Convention. From that perspective the role of ECRML as a tool which shapes the new dimension of Conventional linguistic rights approach shall not be overrated. Finally, it is essential to bear in mind that both the Charter and the Convention are legal instruments of different natures, from which the first protects languages and the second all human rights. Nevertheless, some authors raise concern regarding the conflict of ECRML and the Article 14 of the Convention as well as the conflict with some substantial rights, including the right to education (Brosig, 2016, p. 336).

Such an opinion has been confirmed by the legal heritage of the Venice Commission as the question raised is not whether linguistic rights must benefit from a collective guarantee at the European level but whether the creation of a hard core on the basis of the provisions of ECRML is an appropriate way to ensure these rights (Venice Commission, 2011, p. 26).

The Venice Commission appropriately states that criteria allowing the person to belong to the minority to exercise this right in its relations with the public administration are not clearly laid down. Moreover, many provisions of the ECRML are restricted by the clause 
"within the rule of law" (Venice Commission, 2011, p. 27). The opinions of Venice Commission are certainly becoming factors which may strengthen the significance of ECRML. For instance, the Venice Commission considers that it would be welcome, in order to enhance legal certainty for all minorities as well as for majority, that the law itself would contain precise provisions on the number of requests that are necessary to guarantee an enforceable right to have such schools established or maintained.

Another important external factor is the Framework Convention for the Protection of National Minorities (hereinafter FCNM). In accordance with the Article 14(1) of FCNM, the Parties undertake to recognize that every person belonging to a national minority has the right to learn his or her minority language. Moreover, Article 14(2) stipulates that in areas inhabited by persons belonging to national minorities traditionally or in substantial numbers, if there is sufficient demand, the States shall endeavor to ensure, as far as possible and within the framework of their education systems, that persons belonging to these minorities have adequate opportunities for being taught the minority language or for receiving instructions in this language (FCNM, 1995).

In accordance with the Explanatory Report to the FCNM, the obligation to recognize the right of every person belonging to the national minority to learn their minority languages provides no exception as the basic mean by which individuals can preserve their identity. However, such a regulation does not imply any positive actions. In recognition of the possible financial, administrative and technical difficulties associated with instructions in minority languages, the provision has been worded very flexibly, leaving States a wide margin of discretion. The obligation to endeavor to ensure instructions in minority languages is subject to several conditions, in particular the "sufficient demand" from persons belonging to the relevant national minorities (FCNM, 1995, p. 21).

Through the criterion of the wide margin of discretion, the standard of FCNM resembles the initial stage of ECtHR judicial practice. Oppositely to the ECtHR, the FCNM explicitly recognizes the minority languages education, but the flexibility and vagueness of analyzed provision pose a threat to its efficiency. In this case it is essential to refer to the approach of the Venice Commission which postulates the necessity of adequate opportunities for teaching and in minority languages, clear criteria and procedures in line with applicable standards and taking into account the existing needs (Venice Commission, 2011, p. 32).

\section{Conclusions}

To conclude the authors claim that the ultimate recognition of the aforesaid right is primarily dependent on the further development of the judicial practice of the ECtHR. From that perspective it shall be emphasized that previous judicial practice is relatively incoherent and therefore unforeseeable. The conducted analysis has disclosed the visible conflict between the static interpretation of the ECHR which is associated with the will of its drafters to significantly restrict the rights of the minorities and the living tree doctrine. The aforesaid 
doctrine relies upon promoting a theory of judicial interpretation, which specifically empowers judges to develop and entrench new positions and which assigns a key role to judicial findings in adapting law to evolving societal conditions (Morris, 2018, p. 105). Since any of the presented concepts has not achieved an ultimate victory the presented problems still remain unsolved. Moreover, the indicated jurisprudence of the ECtHR reveals the collision between the distinct aspect of the margin of appreciation doctrine - the provision of $\mathrm{P} 1-2$ provides a relatively wide margin of discretion, but simultaneously contrary to the initial judgments, such a margin becomes narrow in the cases of primary and secondary education. Therefore, the subsequent judgments of the ECtHR will be reliant on the circumstances of the concrete case, inter alia the respondent State.

In the view of the authors of the article, other instruments guaranteed in the Strasbourg systems will not become decisive factors to change the European approach towards the presented issue. The rationale for such conclusions is significantly different in cases of various legal tools. The FCNM, similarly to the Convention provides the wide margin of discretion and flexibility for the States concerned and what is even more important is subjected to the condition of sufficient demand. Oppositely, the ECRML despite the wide scope of impingement protects solely languages and does not constitute the rights of general nature. Through such a prism the Convention still remains an instrument with the greatest potential to reach a general recognition of the right to education in minority language. However, the most vital obstacle to achieve such an aim is the construction of the provision of P1-2 as a guarantee of parental rights in education, not the State obligation to create a certain model of educational system.

\section{References}

Access to German Minority Schools in Upper Silesia, Advisory Opinion, 1931 P.C.I.J. (ser.A/B) No. 40 (May 15). Arai,Y.,Arai-Takanashi, Y. (2002). The Margin of Appreciation Doctrine and the Principle of Proportionality in the Jurisprudence of the ECHR, Antwerp, Oxford, New York: Intersentia.

Beiter, K. D. (2006). The Protection of the Right to Education by International Law, Leiden-Boston: Martinus Nijhoff Publishers.

Brosig, M., Timofey, A. (2016). Trajectories of Minority Rights Issues in Europe: The Implementation Trap?, New York: Routledge.

Case relating to the certain aspects of the laws on the use of languages in education in Belgium versus Belgium from 23.071968, nos. 1474/62, 1677/62, 1691/62, 1769/63, 1994/63, 2126/64.

Catan v. Moldova and Russia from 19.10.2012, nos. 43370/04, 8252/05, and 18454/06 with partly dissenting opinion of judge A. Kovler.

Christoffersen, J. (2009). Fair Balance: A Study of Proportionality, Subsidiarity and Primarity in the European Convention on Human Rights, The Hague: Martinus Nijhoff Publishers.

Coomans, F. (1988). Clarifying the Core Elements of the Right to Education. Retrieved from: http:// aihrresourcescenter.org/administrator/upload/documents/core.pdf, p. 1-15.

Council of Europe (1967). Preparatory work on Article 2 of the Protocol to the Convention, 9 May 1967, Strasbourg, $\mathrm{CDH}(67) 2$. 
Cumper, P., Wheatley, S.C. (1999). Minority Rights in the "new" Europe, Hague/London/Boston: Martinus Nijhoff Publishers.

Cyprus v. Turkey from 10.05.2001, No. 25781/94.

European Commission for Democracy through Law (Venice Commission) (2011), Compilation of Venice Commission Opinions and Reports Concerning the Protection of National Minorities. CDL(2011)018, Strasbourg: the Council of Europe.

Kiestra, L.R. (2014). The Impact of the European Convention on Human Rights on Private International Law. Maastricht: Springer.

Koch, E.I. (2009). Human Rights As Indivisible Rights: The Protection of Socio-economic Demands under the European Convention on Human Rights, Leiden/Boston: Martinus Nijhoff Publishers.

Lenzerini, F. (2014). The Culturalization of Human Rights Law, Oxford: Oxford University Press.

Morris, S.P. (2018). Russian Discourses on International Law: Sociological and Philosophical Phenomenon, Abington: Routledge

Özersay, K., Gürel, A. (2009). The Cyprus Problem at the European Court of Human Rights [in:] Tocci, N., Diez, T. (eds.) Cyprus: A Conflict at the Crossroads, Manchester: Manchester University Press.

Loizidou v. Turkey from 18.12.1996, No. 15318/89.

Minority Schools in Albania, Advisory Opinion, 1935 P.C.I.J. (ser. A/B) No. 64 (Apr. 6).

Ruiz Vieytez, E.J., Dunbar, R. (2007). Human Rights and Diversity: New Challenges for Plural Societies, Bilbao: Humanitarian Net.

Saul, B., Kinely, D., Mowbray, J. (2014). The International Covenant on Economic, Social and Cultural Rights: Commentary, Cases and Materials, Oxford: Oxford University Press.

Schabas, W.A., (2013). The Universal Declaration of Human Rights: The Travaux préparatoires, Volume I - October 1946 to November 1947, Cambridge: Cambridge University Press.

Schabas, W.A. (2015). The European Convention on Human Rights: A Commentary, Oxford: Oxford University Press.

Skender v. the former Yugoslav Republic of Macedonia from 22.11.2001, No. 62059/00.

Vahl, M., Emerson, M. (2004). "Moldova and the Transnistrian Conflict", Journal on Ethnopolitics and Minority Issues in Europe, 1, 2004.

Woerhling, J.-M. (2005). The European Charter for Regional Or Minority Languages: A Critical Commentary, Strasbourg: The Council of Europe.

Yourow, H.C. (1996). The Margin of Appreciation Doctrine in the Dynamics of European Human Rights Jurisprudence, The Hague/Boston/London: Martinus Nijhoff Publishers.

\section{Authors}

\section{Hanna Wiczanowska}

Adam Mickiewicz University, Faculty of Law and Administration.

Contact details: hanna.wiczanowska@amu.edu.pl; Adam Mickiewicz University Room 210, Collegium Iuridicum, ul. Św. Marcin 90, Poznań

\section{Łukasz Szoszkiewicz}

Adam Mickiewicz University.

Contact details: 1.szoszkiewicz@amu.edu.pl; Adam Mickiewicz University Room 210, Collegium Iuridicum, ul. Św. Marcin 90, Poznań 